\title{
A Celebration of Life XVII: Geology on Earth and Mars! Summer Science for Grades 3-5 and 6-8
}

\author{
Barbara Bielec \\ BioPharmaceutical Technology Center Institute
}

\begin{abstract}
The primary goal of "A Celebration of Life" is to support the continued development of African American and other students' interest in science, and to assist in providing them with the tools for success in school. A long-term goal is to increase the number of minority students who successfully complete high school science courses and who choose to pursue STEM careers. In partnership with the African American Ethnic Academy, Inc. (AAEA), a Madison non-profit organization, the BioPharmaceutical Technology Center Institute (BTC Institute) offered "A Celebration of Life XVII: Geology on Earth and Mars!" during summer 2012. Two week sessions, one for elementary and one for middle school students, were held weekday mornings at the BioPharmaceutical Technology Center, in Madison, Wisconsin. These programs represent a 17-year collaboration between AAEA and the BTC Institute that prioritizes offering a rich range of hands-on science activities for students.
\end{abstract}

\section{Introduction}

The primary goal of "A Celebration of Life" is to support the continued development of African American and other students' interest in science, and to provide them with tools for success in school. A long-term goal continues to be increasing the number of minority students who successfully complete high school science courses, and who may eventually choose to pursue science, technology, engineering and math (STEM) careers. Extensive efforts are made to ensure participation of students from economically challenged families through the provision of scholarships and transportation.

\section{Program Details}

The program theme for 2012 was Geology on Earth and Mars! The elementary program was held weekday mornings June 18-29, the middle school program was held July 2-13. For both sessions, hands-on activities, in outdoor, classroom and laboratory settings, were designed to engage students' interest in science and STEM careers. This was accomplished through a series of activities about the exploration of Geology on Earth and Mars that were related to the Mars Rovers, including Curiosity. Program activities reflect the Wisconsin Model Academic Standards for Science, which follow the form and content of the National Science Education Standards. Many of the educational activities were from the NASA Summer of Innovation Project (http://www.nasa.gov/offices/education/programs/national/summer/home/index.html, 2012).

The BTC Institute is pleased to acknowledge the Wisconsin Space Grant Consortium Special Initiatives Program and the NASA Summer of Innovation Project for their financial support. 
Over two-thirds of the student participants were African American, and 79\% of all participants belong to an underrepresented minority group. Many participants received scholarships and transportation to facilitate their participation in the program. A total of 29 students: 13 girls $(45 \%)$ and 16 boys (55\%), participated in developmentally appropriate learning.

Table 1: Gender of Participants in A Celebration of Life XVII: Geology on Earth and Mars!

\begin{tabular}{|l|l|l|l|}
\hline Program & $\begin{array}{l}\text { Total } \\
\text { Participants }\end{array}$ & Girls & Boys \\
\hline $\begin{array}{l}\text { Geology on } \\
\text { Earth and Mars } \\
\text { Elementary }\end{array}$ & 18 & 9 & 9 \\
\hline $\begin{array}{l}\text { Geology on } \\
\text { Earth and Mars } \\
\text { Middle School }\end{array}$ & 11 & 4 & 7 \\
\hline Total & 29 & 13 & 16 \\
\hline
\end{tabular}

Table 2: Ethnicity of Participants in A Celebration of Life XVII: Geology on Earth and Mars!

\begin{tabular}{|l|l|l|l|l|}
\hline Program & $\begin{array}{l}\text { Total } \\
\text { Participants }\end{array}$ & $\begin{array}{l}\text { African- } \\
\text { American }\end{array}$ & Hispanic & Other \\
\hline $\begin{array}{l}\text { Geology on } \\
\text { Earth and } \\
\text { Mars } \\
\text { Elementary }\end{array}$ & 18 & 10 & 3 & 5 \\
\hline $\begin{array}{l}\text { Geology on } \\
\text { Earth and } \\
\text { Mars } \\
\text { Middle School }\end{array}$ & 11 & 10 & & 1 \\
\hline Total & 29 & 20 & 3 & 6 \\
\hline
\end{tabular}

All specific topics for both sessions of the summer 2012 Geology on Earth and Mars! program were related to NASA's exploration of Mars, and many of the educational activities used were designed by NASA to include the following content:

-rocks on Earth and Mars

-volcanos

-geological evidence of water

-current NASA projects related to geology, including Mars Rovers

- historic and contemporary African American science, technology, engineering and math (STEM) professionals, including those affiliated with NASA 
Each session also included a field trip and concluded with student presentations of selected activities to their peers, family members and other adult guests on the last day of each session. Students also shared their posters of African American STEM Professionals.

\section{Results}

Pretests and post-tests are administered as part of each AAEA/BTC Institute summer science program as one indicator of students' learning. Overall, both elementary and middle school students showed an increased knowledge about geology, Mars exploration and African American STEM professionals.

For example, on the pretest only $21 \%(3 / 14)$ of the elementary students tested could name a single African American Scientist, Engineer or Mathematician, and two of the answers were "George Washington Carver" - a good, but certainly not current, example. On the post-test $94 \%(15 / 16)$ of the students could list 3 or 4 African American STEM Professionals we had featured.

Elementary students were also asked: "Earth's atmosphere helps protect us from Mars does not have much atmosphere so there is little protection from this." Multiple choices for fill in the blank: a rain, b. ultraviolet light, c. gravity, d. space monsters.

On the pretest $43 \%$ answered "ultraviolet light" correctly, on the post test $88 \%$ did so.

Scientific content knowledge can be measured by the pre- and post tests, providing information regarding one aspect of program assessment. Another key indication of success is the number of students who had participated in previous AAEA/BTC Institute programs, or who had family members who were previous participants. In the 2012 summer program, participants included 29 elementary and middle school students total. Of those 29 students, 52\% had previously participated, or have had family members who have participated. Of the total number $34 \%$ have participated for $3+$ years! All of the middle school participants, except for one, had previously participated in the program.

In addition a former student, now in high school, who had attended the program for 5 years, volunteered with both elementary and high school programs as an assistant. Also, three of the "graduating" $8^{\text {th }}$ grade students expressed interest in volunteering for future summer programs.

The return rate of students, along with excellent attendance throughout both sessions, is strong evidence that this program is valued by the participants and their families. When students return for the third, fourth, fifth or sixth year, it is a strong indication of their interest in science programming. 
Table 3: Participants in A Celebration of Life XVII: Geology on Earth and Mars!

\begin{tabular}{|l|l|l|l|}
\hline Program & $\begin{array}{l}\text { Total } \\
\text { Participants }\end{array}$ & $\begin{array}{l}\text { Participants } \\
\text { in Previous } \\
\text { Programs }\end{array}$ & $\begin{array}{l}\text { First Year } \\
\text { of } \\
\text { Eligibility } \\
\text { (Grade 3) }\end{array}$ \\
\hline $\begin{array}{l}\text { Geology on } \\
\text { Earth and Mars } \\
\text { Elementary }\end{array}$ & 18 & 5 & 3 \\
\hline $\begin{array}{l}\text { Geology on } \\
\text { Earth and Mars } \\
\text { Middle School }\end{array}$ & 11 & 10 & NA \\
\hline Total & 29 & 15 & 3 \\
\hline
\end{tabular}

The following local news article helps describe the impact that the AAEA/BTC Institute program Geology on Earth and Mars! had on its participants and the community. From The Madison Times, July 18, 2012, "A Celebration of Life XVII Geology on Earth and Mars", by David Dahmer:

"On July 13, a group of middle school students celebrated the completion of "A Celebration of Life XVII" program, a two-week course offered through the collaborative efforts of the African American Ethnic Academy (AAEA) and BioPharmaceutical Technology Center (BTC) Institute. This program affords children an opportunity to expand their scientific knowledge by conducting hands-on experiments.

"Great minds got together and a wonderful program was born 17 years ago," ways Barbara Bielec, BTC Institute K-12 program director. "I've had the fortune to work with this program for 10 years now".

This year's theme was "Geology on Earth and Mars!" It was especially exciting for the kids because on Aug. 5, NASA's 1-ton Curiosity rover, the centerpiece of the Mars Science Laboratory (MSL) mission, is slated to land on the Martian surface to investigate whether the planet is, or ever was, capable of harboring past or present microbial life.

"Curiosity' is landing and this program is all about stimulating curiosity" Bielec said. "We're really trying to encourage the development of STEM [science, technology, engineering and math] professionals. We're doing programs every summer to encourage kids to keep taking math and science courses so that we have a diverse workforce in the future."

The students spend their summer mornings studying, learning, and going on field trips or listening to guest speakers who are often African-American STEM professionals who are related to the topic of the summer - this summer it was geology. A long-term objective is 
to increase the number of minority students who enroll in - and successfully complete high school science courses, and who eventually choose to pursue scientific careers.

At the celebration, the kids took turns showing off things they learned during the summer course whether it be giant billboards of famous African American scientists and geologists or scientific experiments. Program founder Dr. Virginia Henderson handed out certificates to all of the youngsters before they had a pizza party." (Dahmer, 2012)

Comments from the students who participated also speak to the impact of the Geology on Earth and Mars! program. When asked on the post test, "Would you like to become a STEM Professional when you grow up? Why or why not?" the responses (spelling corrected) included:

- "Yes. Because I am really interested in Science, Math and Technology. I also want to get smarter in any way I can. The smarter I get, the more successful I will be throughout the rest of my life."

- "I do because I like all those things... and today I want to be a scientist when I grow up because it is fun doing and learning new things."

- "Yes. I want to create Rovers and roads."

- "I might be an Engineer because I really like building stuff."

- "I'd like to be an astronomer like Eric Wilcots. Dr. Wilcots inspired me to be one with his vast knowledge of stars." (Note: Dr. Eric Wilcots was one of our guest speakers and featured African American STEM Professionals. Dr. Wilcots is an Associate Dean at the University of Wisconsin-Madison and a Professor of Astronomy. )

\section{Conclusion}

The National Science Foundation (NSF) report, entitled Women, Minorities, and Persons with Disabilities in Science and Engineering: 2011, noted that: "Underrepresented minorities [blacks, Hispanics, and American Indians] share of science and engineering bachelor's and master's degrees have been rising over the two decades since 1989, with shares of doctorates in these fields flattening after 2000. The greatest rise in science and engineering bachelor's degrees earned by underrepresented minorities has been in the social, computer, and medical sciences fields of study." However, this increase in STEM degrees still does not show equivalency with the population percentage of underrepresented minority groups in the U.S. population. From data presented in the NSF report African Americans comprised only 3\% of the "Scientists and engineers in science and engineering occupations: 2006". The report concluded that: "The science and engineering workforce is largely white and male. Minority women comprise fewer than 1 in 10 employed scientists and engineers." (NSF, Women, Minorities, and Persons with Disabilities in Science and Engineering: 2011) Supporting African American educational opportunities in science is essential to helping increase the number of African American students who will ultimately go into baccalaureate and graduate programs in science. 
A National Science Teachers Association feature article about science education programs that successfully engage underrepresented students describes the importance of culturally relevant content: "Teachers should discuss African-American scientists throughout the course, not just during Black History Month. Although textbooks may still lack adequate connections between science content and minority scientists, the internet is a great source to find individuals linked to specific stages of scientific development. Minority students will identify with these role models, and thus begin to personalize the science concepts and consider careers in science." (Bardwell and Kincaid, 2005)

This is in agreement with a study that specifically examined the influence of race and gender role models on young adolescents, where the author found that "the availability of race- and gendermatched role models showed a strong relationship to the developing identities of young adolescents. The availability of a race- and gender-matched role model was significantly and consistently predictive of a greater investment in achievement concerns on the part of these young adolescents." (Zirkel, 2002). The AAEA/BTC Institute programs will continue to focus on African American STEM professional role models to help inspire students in these areas.

This approach is in alignment with the goal and objectives of the National Space Grant Program, 2010-2014. "The goal of the Space Grant Program is to contribute to the nation's science enterprise by funding education, research, and informal education projects through a national network of university-based Space Grant consortia." One of the objectives of the Space Grant Program is to: "Promote a strong science, technology, engineering, and mathematics education base from elementary through secondary levels while preparing teachers in these grade levels to become more effective at improving student academic outcomes." A second objective is to: "Recruit and train U.S. citizens, especially women, underrepresented minorities, and persons with disabilities, for careers in aerospace science and technology." (National Space Grant College and Fellowship Program [Space Grant] 2010-2014)

The support provided by the Wisconsin Space Grant Consortium helps the A Celebration of Life! summer science program meet both of these objectives, and the overall goal of the Space Grant Program. A Celebration of Life! has helped to provide a "strong science, technology, engineering and mathematics education base" for both upper elementary and middle school secondary students. The exploration opportunities provided by the summer program enrich and enhance students' scientific knowledge and associated skills. It is also essential for students to see themselves in those roles. Learning about historic and contemporary African American STEM professionals as part of an exciting hands-on science program will help to recruit a diverse work force of problem solvers, scientists, inventors and engineers for "careers in aerospace science and technology".

The National Space Grant Program 2010-2014 further defines one of its priorities: "NASA Education Priorities, Current Areas of Emphasis - Authentic, hands-on student experiences in science and engineering disciplines - the incorporation of active participation by students in hands-on learning or practice with experiences rooted in NASA-related, STEM-focused questions and issues; the incorporation of real-life problem-solving and needs as the context for activities." (National Space Grant College and Fellowship Program [Space Grant] 2010-2014). The many NASA Education Mars exploration activities incorporated in the Geology on Earth and Mars! summer 2012 sessions were certainly successful examples of "active participation by students in hands-on science" learning related to current "real-life" NASA projects. Another name for the program? Curiosity? 


\section{References}

Bardwell, Genevieve and Kincaid, Eric. The Science Teacher, February 28, 2005. A Rationale for Cultural Awareness in the Science Classroom. http://www.nsta.org/publications/news/story.aspx?id=50285\&print=true

Dahmer, David. The Madison Times, A Celebration of Life XVII Geology on Earth and Mars”, July 18, 2012.

NASA Summer of Innovation Project, 2012. Available at

http://www.nasa.gov/offices/education/programs/national/summer/education_resources/index.html

National Science Foundation, Division of Science Resources Statistics. 2011. Women, Minorities, and Persons with Disabilities in Science and Engineering: 2011. Special Report NSF 11-309. Arlington, VA. Available at http://www.nsf.gov/statistics/wmpd/.

National Space Grant College and Fellowship Program (Space Grant) 2010-2014. National Aeronautics and Space Administration Office of Education FY 2010 NASA Training Grant Announcement. Release Date: 30 November 2009. http://www.nasa.gov/pdf/418826main_Space\%20Grant\%202010\%20Solicitation\%20Rev\%20B[1].pdf

Zirkel, Sabrina. Teachers College Record Volume 104, Number 2, Is There A Place for Me? Role Models and Academic Identity among White Students and Students of Color, 2002, Teachers College, Columbia University. 